\title{
The Issue of 'World Political Authority' in the Broader Context of Catholic Social Thought
} Roman Míčka

'The human race, although it is divided into various nations and kingdoms, always has a certain unity, not only a specific one, but also as it were a political and moral one. That places a natural requirement of mutual love and mercy due to all, even to foreigners and anybody else.'

Francisco Suárez, De legibus, 1612

\section{By way of introduction}

In connection with the contemporary 'migration crisis' many political, philosophical and ethical issues have once again come to the fore, are being thought through again, and answers are being offered from various ideological perspectives. The present point of view will consist primarily in the impulses and reflection of the social teaching of the Catholic Church (CST). This paper does not have the ambition to address the issue of migration in all of its breadth, depth and essence - the phenomenon of migration and its ethical aspects from the point of view of CST positions have already been in their substance subjected to detailed reporting and reflection, in the Czech milieu especially due to the publication activity of Petr Štica. ${ }^{1}$ Nonetheless, in this context I would like to select, recall and somewhat develop one aspect, which is in essence permanently present in the tradition of Christian socio-ethical thought - even long before the origin of CST itself. It is the possible political and institutional expression of the 'cosmopolitan principle', viz. the concept of humanity's moral unity, which is a firm assumption of Christian socio-ethical thought. CST, especially since the era of the pontificate of Pius XII, has associated the 'cosmopolitan principle' of the moral unity of humanity - narrowly linked to the principle of personality, the equal dignity of all humans, the principle of solidarity and the principle of the universal destination of goods - with the requirement of a certain global political institutionalized organization of humanity headed by a 'world political authority'. This principle stands in a certain tension and complementarity to the 'political principle' - viz. the right of individual particular human communities to political autonomy and the specific formulation of their way of life, whereby the two constitute a frame of reference for reflection on the issue of migration, as well as on a whole range of topics of international policy. Benedict XVI emphasized the idea of 'world political authority' (Lat. auctoritas politica mundialis) anew in his encyclical Caritas in veritate - in connection with the pressing character of the economic crisis of the time, he requested a higher level of international

1 See Petr ŠTICA, Migrace a státní suverenita: oprávnění a hranice přistěhovalecké politiky z pohledu křestanské sociální etiky, Červený Kostelec: Pavel Mervart, 2010; Petr ŠTICA, Migrace v sociálním učení církve, AUC Theologica 1/2012, pp. 113-135. 
ordering, which would be aimed at realizing the common good, true integral development and the realization of a social order corresponding to the moral order. According to the encyclical, such international ordering urgently requires the existence of a true world political authority to oversee globalization, the world economy, the redistribution of wealth, and protection of the environment, as well as migratory movement. ${ }^{2}$

\section{World political authority in CST}

The notion of an international authority assumes that the individual states and human communities are not absolutely sovereign, but must in certain aspects be subordinate to the moral unity of humanity and the requirements of a 'global common good'. The notion of world political authority may be searched for deeper in history, but the tradition of papal social documents received the idea from neo-scholastic thought and, of course, also in reaction to the pressing historical calls for a functioning international order in reaction to WWII. The Church documents and the views of the popes show that the ideal of a whole-world political authority is not a contingent and context-dependent topic, but a notion to which the popes repeatedly return with different emphases, and have elaborated upon, in different ways since the time of Pius XII up to the present. ${ }^{3}$ A certain variance in the expected breadth of the agenda the global authority was to secure can be observed between the individual periods and documents. Pius XII conceives it prevalently as an 'organ of peace-keeping;' John XXIII, on the other hand, did so in a substantially broader way as an organ with economic, social and cultural powers. ${ }^{5}$ The Second Vatican Council document Gaudium et spes confirms a more modest conception of world authority to secure world peace, justice and human rights. ${ }^{6}$ John Paul II stresses that the international order is primarily a matter of respect for moral values, and not strong international political institutions. ${ }^{7}$ In the present context the notion of world political authority is elaborated on in greatest detail by Benedict XVI. To the preceding popes' doctrine of global political authority he adds new accents to the subsidiary, multi-level and polyarchic character of the international order, so that it cannot become a 'universal power of a tyrannical nature'. However, he sees the competences of such an authority quite broadly, as indicated above. Pope Francis requests the reinforcement of international institutions with respect to the governance of global goods ${ }^{8}$ (the context shows that he is thinking especially of the sphere of ecology and natural resources, as well as eradicating the most serious forms of poverty), but at the same time he places a surprisingly enormous emphasis on local solutions and the autonomy of states. Concerning the requirement on the character and orientation of this authority other accents can be distinguished as well - while Popes John XXIII and Francis emphasize the issue of securing basic material and social conditions for all humanity, Pius XII and John Paul II

2 Cf. BENEDICT XVI, Caritas in veritate (online), at: http://w2.vatican.va/content/benedict-xvi/en/encyclicals/documents/hf_benxvi_enc_20090629_caritas-in-veritate.html, art. 67. Further only CV and section number.

3 I report on this issue in more detail in another paper (Roman MÍČKA, Idea Global Governance ve světle sociálního učení církve, Revue církevního práva 54-1/2013, pp. 17-31). In this overview study I partially make use of some of the information, evaluations and conclusions published there.

4 Cf. PIUS XII, Mír ze spravedlnosti. Výbor projevů pronesených ve válečných letech 1939-1945, Praha: Atlas, 1947, p. 200.

5 JOHN XXIII, Pacem in terris (online), at: JOHN XXIII, http://w2.vatican.va/content/john-xxiii/en/encyclicals/documents/hf_j-xxiii_ enc_11041963_pacem.html, art. 137-141. Further only PT and section number.

6 Cf. Gaudium et spes, Pastoral Constitution on the Church in the Modern World (online), at: http://www.vatican.va/archive/hist_ councils/ii_vatican_council/documents/vat-ii_cons_19651207_gaudium-et-spes_en.html, art. 82.

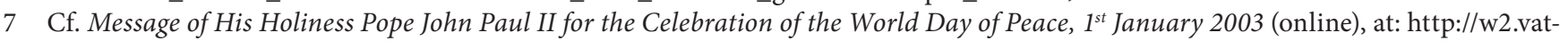
ican.va/content/john-paul-ii/en/messages/peace/documents/hf_jp-ii_mes_20021217_xxxvi-world-day-for-peace.html, art. 6.

8 Cf. FRANCIS, Laudato si' (online), at: http://w2.vatican.va/content/francesco/en/encyclicals/documents/papa-francesco_20150524_ enciclica-laudato-si.html, art. 173-174. 
associate these requirements concerning world political authority rather more strongly with the ideals of democracy.

The many conditions placed by CST documents on world political authority may as a whole appear somewhat contradictory - 'it must be set up with the consent of all nations, not imposed by force'; it 'must operate with fairness, absolute impartiality, and with dedication to the common good of all nations'; it must not 'limit the sphere of action of the individual states; $;{ }^{\prime 10}$ it must be 'universally recognised and vested with the effective power to ensure security for all, regard for justice, and respect for rights'; it is to move towards 'the construction of a social order that at last conforms to the moral order'; ${ }^{11}$ and must not be a 'universal power of a tyrannical nature'12 - in this sense the ideal of world political authority appears as a point of reference, yet as a project that could hardly be realized by political means.

In the broader context of CST somewhat stronger requirements on global structures are raised - these are contained, for example, in the nota of the Pontifical Council for Justice and Peace (IUPAX) of 2011. ${ }^{13}$ The document gives a detailed analysis of the notions of the economic and financial dimension of the global authority's management, which it associates with a reform of the international monetary system, the creation of a World Central Bank and the regulation of international financial transactions. By its character the document finds the key agenda of the global authority in the economic sphere. Although it regards the UN as a starting point for global governance, it is obviously formulating quite new - parallel - institutions and the architecture of an international order ('The establishment of a world political Authority should be preceded by a preliminary phase of consultation from which a legitimated institution will emerge that is in a position to be an effective guide and, at the same time, can allow each country to express and pursue its own particular good.'), which does not reckon with the automatic involvement of all countries of the world, but only with those that freely join in the new architecture ('governments should not serve the world Authority unconditionally'). With respect to detailed formulation of particular institutions and processes the question suggests itself as to whether the note in some respect does not cross the limits of what is normally regarded as the competence of CST.

The tradition of CST constitutes a key frame of reference for the development of a somewhat broader spectrum of thought and reflection - 'Catholic social thought'. That is represented by a broad spectrum of authors, who further reflect on political and economic issues from Catholic positions, whether with a narrower, or rather a weaker link to CST. That is also why a broader fan of approaches is found here, reflecting the opinions and ideological background of the individual authors, or the specific historical and contextual differences. That is a legitimate and expected approach because CST as such is characterized by a certain level of generality and does not have the ambition to propose the particular form of political institutions - in the sphere of evaluating the particular 'technical solutions' of political and economic facts CST does not claim exclusivity or infallibility and acknowledges the legitimacy of a plurality of views and strategies towards the realization of the key values. So Catholic social thought further creatively develops CST incen-

9 Both in PT 138.

10 PT 141.

11 Both in CV 67.

12 CV 57.

13 (C) Towards Reforming the International Financial and Monetary Systems in the Context of Global Public Authority, 2011 (on-line), at: http://www.vatican.va/roman_curia/pontifical_councils/justpeace/documents/rc_pc_justpeace_doc_20111024_nota_en.html, accessed 29th September 2016. 
tives and attempts to further develop, interpret, specify and formulate possible particular models of the functioning of social reality. In particular cases and situations, different models and forms of institutional ordering can legitimately arise. Of course this interpretative potential and plurality of views are also applied in questions concerning global political organization, international relations and global political authority. Of course, the requirement of a world political authority, which is in a certain way non-obvious, raises certain hopes of progress in international relations based on historical precedents and debates, as well as present ideological positions, but at the same time it also generates many questions, controversies and risks, even within the tradition of Catholic social thought as such. I will now present and evaluate this colourful and complex debate (especially with reference to the last two decades), which further develops or concretizes possible approaches to the issue of world political authority and in a broader sense also of global governance $(\mathrm{GG})$, which comprises a broader fan of notions of the international order.

\section{Incentives on the issue of global governance more closely associated with the institutional Church milieu}

The prospects of global governance are extensively covered by the Report to Bishops of COMECE of 2001. ${ }^{14}$ It is not a document published by a Church authority, but a text written by a special group of experts - the text is formulated as a challenge to debate the issue of global governance to COMECE, Christians, and to all persons of good will, which has principally become an impulse to subsequent, more dynamic development of this concept in the context of Catholic social thought. Right at the beginning (in the Foreword formulated by Bishop Josef Homeyer, then President of COMECE) the document makes an important distinction - the concept of GG is conceived as directly opposite to global government ('Global governance, as opposed to global government, means a networked approach to global problems that involves governments, business and non-governmental organisations as well as Churches and other religious communities.') $)^{15}$ At the same time it associates the concept of GG with the project of European integration, which has been successful and can serve as an exemplar:

The EU has a crucial role to play in developing the existing international order into a system of global governance. We consider that the European Union is a pioneering model of regional integration, setting an example for the future of governance in many other regions of the world, despite its still nascent and therefore contingent character in some policy areas. ${ }^{16}$

The report acknowledges inspiration in the idea of the requirement and the 'prophetic vision' of the need for a global political authority, expressed by John XXIII in the encyclical Pacem in terris. It regards its incentives towards reinforcing the system of GG as a path towards that end. The text contains a general analysis of the present state, then a proposal of a set of key values and principles for $G G$ according to CST, and, further, also specific proposals for its gradual institution and implementation. The report understands the concept as a prerequisite of the realization of the global common good and the key to the realization of the positive impacts of globalization, while

14 () Global Governance. Our responsibility to make globalisation an opportunity for all, 2001 (on-line), at: http://siteresources.worldbank. org/DEVDIALOGUE/Resources/GlobalGovernance.pdf, accessed 29th September 2016.

15 Ibid, p. 3.

16 Ibid, p. 3-4. 
at the same time eliminating the negative impacts. It does not intend to propose an altogether new system of global institutions, but to invite the reform, adaptation and reformulation of the present ones. It stresses that:

Global governance does not mean global government in the form of a centralised body that holds exclusive world power and controls global economic flows and information. Rather, it would provide the capacity for effective and legitimate political decision making at the global level through international institutions and structures of co-operation, co-ordination and perhaps even shared sovereignty. ${ }^{17}$

In such a system the consensus would still be based on the consensus of nation states, which would still be the basic units, at least in foreseeable future, before they adapt to new global changes. The document finds the ethical core for supporting and realizing GG in a set of key values and principles according to CST (respect to human dignity, responsibility, solidarity, subsidiarity, coherence, transparency and responsibility), whereby it regards churches and other religious societies as key agents in enforcing these values. Human dignity is protected by human rights - although here the document is not referring to the Universal Declaration of Human Rights of the UN, but rather surprisingly proposes the EU Charter of Fundamental Rights as a model. ${ }^{18}$ In the context of globalization the document views two present challenges as crucial: 'to preserve the environment for the generations that will follow us and to offer more and better opportunities to the poorest". ${ }^{19}$ Concerning specific gradual steps of the effective institution and implementation of the GG system, the report proposes the provisional institution of a Global Governance Group, not based on the UN ground plan, but rather, since economic issues would be dominant in it, deriving from the platform and ground plan of the International Monetary Fund (IMF) and G7/8. Its members would be 24 representatives of governments whose executive representatives are at present in the IMF council and the World Bank. It would dynamically develop cooperation with the UN, the World Trade Organization, the International Labour Organization and a further newly proposed World Environmental Organization. The system of governance would be based on the horizontal coordination of agents at the global level and include a whole network of responsible agents (non-government organization, business and corporative agents, states and regional blocks). So it would not primarily be a matter of principally reinforcing one institution. Churches and other religious communities would contribute to GG by striving for ecumenism and religious dialogue. ${ }^{20}$

To a certain extent the issues of world political authority and GG are also discussed by some texts of the Pontifical Academy of Social Sciences (PASS). It is an autonomous organization of experts in the social sciences (economy, political science, law, etc.) founded by Pope John Paul II in 1994 with the purpose of providing incentives for the further development of the social teaching of the Church. They are personalities from different currents of opinion and of different levels of relationship to Christianity. The Academy edits numerous volumes of the proceedings of its plenary and other sessions, in which the contributions of members and other invited experts are gathered.

In PASS texts the concept of global governance begins to appear around 2000, namely, for example, in Hakan Bjorkman's paper The Message of the 1999 Human Development Report - Glo- 
balisation with a Human Face in the PASS collection (2000). ${ }^{21}$ There Bjorkman comments on the Human Development Report (United Nations Development Programme, 1999), which already develops the concept of GG in some breadth. Bjorkman emphasizes the Report's recommendation to link the concept of GG to the concept of human rights and reinforce the role of poor countries in global governance. The PASS collection (2001) mentions GG much more frequently, especially in David Crocker's Globalization and Human Development: Ethical Approaches. ${ }^{22}$ Crocker mentions the Report to Bishops of COMECE that we have already discussed and labels it as 'liberal institutionalism' among approaches to GG in political theory. Another approach that, according to him, occurs in the religious milieu is 'radical republicanism', being radically critical of current international institutions, and also the concept of 'cosmopolitan democracy', placing the emphasis on strong democratic participation of citizens, the role of civic society and deliberative approaches. Despite their different normative assumptions, he regards these three approaches to global governance in the context of globalization as compatible and mutually complementary.

In the collection from the plenary session of PASS (2004) Margaret Archer deals with the issue in the paper Social Integration, System Integration and Global Governance. ${ }^{23}$ She finds the main problem of globalization management in the absence of a unifying institution for global governance; the work of the present inter-government institutions is not coordinated, or they are tributary to powerful states. She distinguishes between the requirements of global social and global systemic integration. She evaluates the concept of 'global civic society', often cited in political theory, and oriented to social integration, as too optimistic regarding the real situation and that it is aimed at the elites. In the sphere of systemic integration she critically evaluates the concept of 'cosmopolitan democracy' as utopian, assuming a non-existent consensus concerning democratic values. She concludes that it is difficult to search for a solution that would at the same time solve the deficiencies of social and systemic integration and urges a search for it, albeit without specifying the possible paths to achieve this. Her scepticism derives from her analysis of the long search for a relationship between social and systemic integration in Western democracies, in which, according to her, a high level of systemic and social integration has been achieved at national and partially also international (EU) level through a combination of democratic procedures and social policy.

In the PASS 2008 collection, the issue of GG is discussed by Juan José Llach in the extensive report Main Outcomes of the Work of the Pontifical Academy of Social Sciences on Globalization ${ }^{24}$ edited by him, which brings together the contribution of the whole institution and the preceding publications. Here, thinking about a structured central world government is labelled as utopian and the preferred model is the coordination of decision-making in the international field, which is more manifest (and primary) in the social sphere than in the political one. The activity of the UN and the Security Council, the conclusions of world summits of political leaders coordinating activities directed towards sustainable development, and the International Court of Justice, etc. are labelled as an embryo of worldwide governance. Nonetheless, further reform is requested, especially of the UN, and the requirement for creating a world tax and fiscal system is voiced. The

21 Cf. ( P PASS, The Social Dimensions of Globalization, 2000, pp. 47-55 (on-line), at: http://www.pass.va/content/dam/scienzesociali/pdf/ miscellanea2.pdf, accessed 29th September 2016.

22 Cf. () PASS, Globalization. Ethical and Institutional Concerns, 2001, pp. 45-65 (on-line), at: http://www.pass.va/content/dam/scienzesociali/pdf/actapass7.pdf, accessed 29th September 2016.

23 Cf. (C) PASS, The Governance of Globalisation, 2004, pp. 141-164 (on-line), at: http://www.pass.va/content/dam/scienzesociali/pdf/ actapass9.pdf, accessed 29th September 2016.

24 Cf. () PASS, Summary on Globalization, 2008, pp. 15-93 (on-line), at: http://www.pass.va/content/dam/scienzesociali/pdf/espass12. pdf, accessed 29th September 2016. 
cautious requirement for interconnecting the government of international law and democracy is raised, but at the same time the report says that it is premature to speak of international civil society - ('because in some cases it may serve to mask activities that severely threaten real democracy and other human values'), although this requirement to gradually account for agents of global civic society is regarded as legitimate. At the same time criticism of the UN is voiced reacting to the risks of spreading a deformed vision of the human being: 'At the political and legal levels, however, the UN globalization project looks more worrisome. It has developed a materialist and strictly evolutionist conception of the human being, discarding the realistic vision implicit in its 1948 Declaration.'

In the proceedings of the plenary session of PASS 2010 Vittorio Possenti comments on the issue of GG in his paper The Governance of Globalization: Global Political Authority, Solidarity and Subsidiarity ${ }^{25}$. He is reacting to the revitalized concept of world political authority in the newly published encyclical CV, on which he comments and develops. In his view the international arena lacks the level of political globalization and the structure of authority at the global level. Seeing the close connection between the universal common good and world political authority, it is impossible to be content with 'fragmented political responsibility'. According to Possenti, CST is not following the 'libertarian' concept of GG, which rejects vertical authority and employs only anarchical civic society without authority, and expects the spontaneous constitution of authority or the concept of 'governance without government'. So it advocates (also theologically) a concept of authority, and stresses its necessity and the narrow link between the common good and authority, whereby it views attacks on authority as ideological. It rejects an unstructured and non-subsidiary world state on the one hand, and the absence of a highest authority with unambiguous competences and responsibility on the other. Although it regards a fundamental reform of the UN as very necessary, it nonetheless views this platform merely as a distant precursor of a real world political authority. That must be based on strong cosmopolitanism and the identification of common goals. It regards their effective application as so necessary that, according to Possenti, they may even 'require some sacrifices on the part of full cosmopolitan and democratic legitimacy', so that world political authority could even precede the formation of global civic society, which would be its natural foundation.

Possenti's theses were subsequently subjected to debate, in which, for example, Hsin-chi Kuan is mildly critical of him for an excessively 'theoretical approach'. According to Kuan a more empirical approach would discover that the present structures of global governance do not function quite as badly and unsatisfactorily as Prof. Possenti suggests. Kuan further points out that Possenti gives no indication of the path and mechanism by which the institution of a world political authority should take place, and from where it should draw its legitimacy of origin (if not from sovereign states or a 'global civic society'). The manner of constituting the authority without reaching a consensus of (according to Possenti, obsolete and illegitimately sovereign) national states, i.e., by the path of 'intergovernmentalism' and diplomacy, is unimaginable for him. In general Kuan regards the prospects of instituting a world political authority as highly indistinct and weak. Furthermore, he does not share the frequent view that the model of European integration is a certain exemplar for future GG: 'The question is whether a regional experience can be generalized to the global level. The incomplete success of European integration is the outcome

25 Cf. (C) PASS, Crisis in a Global Economy - Re-Planning the Journey, 2010, pp. 424-441 (on-line), at: http://www.pass.va/content/dam/ scienzesociali/pdf/actapass16.pdf, accessed 29th September 2016. 
of a confluence of very unique factors.' European integration originated in the context of an era following a war of unprecedented destruction, in a situation where the idea of 'nationalism' underwent a fundamental crisis, in a reality of sufficient economic, political and cultural homogeneity, principally shared religious tradition, etc. He also suggests that the EU - despite a high level of integration - also faces significant, difficult problems to solve, e.g. in the fiscal sphere. He even says that it is risky to generalize the European experience to the global level and regards it merely as a useful lesson in the process of realizing a world political authority. At the very end of the paper he poses the rhetorically provocative question as to whether the Church is to play some part in the possible process of searching for a legitimate world political authority.

In his paper Ways to Improve the Order and Governance in Globalising Economic and Financial Markets contained in the proceedings of the PASS plenary session (2012), ${ }^{26}$ Hans Tietmeyer (a former President of the German Central Bank) writes that although the concept of world political authority in Benedict XVI is more elaborate than in John XXIII, it is still too vague and impractical to be realised any time soon'. He even says that not only can't he imagine it being realized soon, he in fact finds it unrealistic. In his view this is even more true regarding the doubtful proposal in the IUPAX document on global authority of 2011, which proposes the institution of a World Central Bank as the first step. In his vision Tietmeyer prefers developing and improving existing institutions to creating new ones. He sees an adequate basis and an important step towards the realization of a more effective GG in the economic sphere in the Financial Stability Board (FSB), founded in reaction to the financial crisis with the purpose of more effective regulation of the financial sector, to which other agents, including the IMF, are bound. He adds that this contractual way deriving from the G20 platform and emphasizing transparency and being freely chosen is 'the best instrument available in the world today to enforce agreed rules - and more effective than compulsory enforcements by a supra-national institution.'

In the PASS proceedings of 2013 the topic of GG is discussed by Rocco Buttiglione in his paper Accountability, Transparency, Legitimacy, Sustainable Development and Governance. ${ }^{27}$ He agrees with the moral obligation of a world order that would care for the proper protection of the world environment and enable all people to share in the goods of the Earth so that they could lead a decent life. But at the same time he objects to the idea of a 'world state' or even a 'world socialist state' for fear of limitations on freedom, plurality and strong redistributive mechanisms at the global level. He says:

What we need is a world governance that respects the rights of the individual states and also those of the market and of civil society and helps all these communities act in such a way that each one of them does not encumber but rather supports the other in the attainment of its legitimate ends.

He conceives this governance primarily as a plurality and an interaction of numerous sovereign subjects - not absolutely sovereign, but each in its own particular order. In his commentary on Buttiglione's text, Janne Haaland Matlary appears to be even more critical of the idea of global governance: he emphasizes the democratic deficiency of supra-national institutions and regimes,

26 Cf. ( ) PASS, The Global Quest for Tranquillitas Ordinis. Pacem in Terris, Fifty Years Later, 2012, pp. 520-534 (on-line), at: http://www. pass.va/content/dam/scienzesociali/pdf/actapass18.pdf, accessed 29th September 2016.

27 Cf. () PASS, Governance in a Changing World: Meeting the Challenges of Liberty, Legitimacy, Solidarity, and Subsidiarity, 2013 (online), at: http://www.pass.va/content/scienzesociali/en/publications/extraseries/governance.html, accessed 29th September 2016. 
saying that the 'upper limit' of democracy is national states - democratic legitimacy, responsibility and a compensating division of power can be applied and confirmed only within their limits. He thinks even the EU is too large to attain the democratic legitimacy of supra-national institutions. Further, he does not regard the often underlined involvement of NGOs in the decision-making processes of global governance as a reinforcement of democratic legitimacy of international institutions, but rather as its weakening - it is a matter of asserting particular, effectively organized interests and ideals.

\section{Views progressively developing the issue of world political authority}

More optimistic views of the concept of GG derive from the assumption that a higher organization of authentic human development is necessary in the context of globalization, applying the principles of justice, solidarity and human unity. They strive to further develop the concept of world political authority sketched in the social encyclicals in the context of different views of the concept of GG in political theory and in associated debates. Of course, the scope of the number of authors and the nuances of opinion could principally always be broadened, but in this paper it will be limited to several representative voices covering the majority of the spectrum of opinion in Catholic social thought. An author who continually speaks for a more strongly conceived GG is, for example, Kevin Ahern, who formulated the document An Introduction to Global Governance Through the Lens of Catholic Social Teaching (2007). This document joins the voices requesting the necessary reform of the functioning of the $\mathrm{UN}$, but without closer specifications except for the more effective use of the platform of the Economic and Social Council (ECOSOC) and improving the functioning of the Secretariat. In the case of the IMF and the World Bank it proposes an effort to attain adequate representation, responsibility and transparency, respect for human rights and just economic and social development. The World Trade Organization is praised for its decision-making system and is regarded as 'the most democratic of all international institutions with a global mandate', although it is prone to manipulation on the part of elite groups and powerful members. Regional cooperative and integration regimes and institutions (African Union, League of Arab States, EU, etc.) are also assigned a key and positive role. The growing phenomenon of global civic society in the form of NGOs is assigned the role of 'guard dogs of globalization', as well as a role in education and asserting values and vision, although the document does not reckon with their involvement in direct political influence and decision-making. At the same time the key role of states as agents of global governance is confirmed:

Nation states remain the principal actors within the international system and whilst agreements are increasingly reached in international contexts, the principal locus of decision-making and implementation remains in the national arena. States continue to be the principal agents capable of taking authoritative decisions. This is why they are the key pillars of the architecture of global governance. ${ }^{28}$

So Ahern's text, in no principal way, steps out of the 'institutional' perspective consisting in the requirement of reforming the existing institutions of global governance. On the other hand, in

28 (c) Kevin AHERN, An Introduction to Global Governance Through the Lens of Catholic Social Teaching, 2007 (on-line), at: http:// www.cidse.org/publications/rethinking-development/global-governance/global_governance_and_catholic_social_teaching.html, accessed 29th September 2016. 
a later debate developed after the publication of the IUPAX note he defends that document and its proposals, although it is thereby clear that he is already tending towards markedly stronger demands for the reform of global institutions. In reaction to incentives in the context of the lively debate in the American milieu - especially to the comment by the Jesuit Thomas J. Reese that the note on the reform of the international financial system contains strongly 'leftist' approaches - Ahern, on the other hand, defends the note and finds its recipes quite consistent with the CST tradition, only developing the topic in the new context of global realities and economic crisis. He even sets the calls for a world political authority in historical context and writes: 'Despite the opposition to structures of global governance from some philosophical and religious ideologies, the Catholic Church has been a strong advocate for international political governance since the early medieval ages.' ${ }^{29}$ Modern Catholic social teaching starting with John XXIII and through John Paul II and Benedict XVI is merely a continuation of this requirement for an effective and 'robust' supranational authority in the context of challenges presented by the global common good. Ahern even regards the note as diplomatically over-correct, mild and abstract; he thinks that it is not sufficiently critical of the key dominant states and corporations, and it does not sufficiently emphasize the role of NGOs and their mediating potential, but it overlooks - since it is elite-oriented - the true reality of poverty in many countries of the world. In a more recent paper Ahern again stresses that 'the Catholic Church has been a leading voice of support for the structures of global governance'. ${ }^{30}$ He says that Pope Francis further reinforces these challenges in the spirit of his emphases on poverty and sustainable development and calls for a reform and adaptation of the UN. According to Ahern Pope Francis is calling for more participatory forms of governance that would not subordinate the human beings of this planet to the ideas and ideologies of governments, not even of the UN system.

Another author to be mentioned in connection with reflecting on the issue of GG is, for example, J. Brian Hehir. In his commentary on the encyclical Caritas in veritate he says that since John XXIII the situation has changed in many areas towards globalization, greater interdependence and also to the experience of great instability of the world economy, including the global economic crisis. While in connection with world political authority John XXIII was primarily thinking of management in the fields of peace, war and human rights, the present globalization and crisis is bringing further unprecedented challenges in the sphere of political economy. He understands the broadening of the role of world political authority to the economic sphere in CV as a logical outcome of the historical shift increasing the role of economy since John XXIII:

The role of a global political authority in directing these institutions is different from and arguably more difficult - economically and ethically - than the challenges faced in John XXIII's day. Benedict's call for such an authority met resistance in financial quarters, but even those in support of his proposal must recognize that balancing the dynamics of freedom and intervention in trade, finance and investments is a more delicate task than addressing the role of sovereign states in the arenas of war and human rights. ${ }^{31}$

29 (c) Kevin AHERN, Global Problems Require Global Governance: The Vatican's Note on Financial Reform, 2011 (on-line), at: http://dailytheology.wordpress.com/2011/10/24/global-problems-require-global-governance-the-vatican\%E2\%80\%99s-note-on-financial-reform/, accessed 29th September 2016.

30 (c) Kevin AHERN, Pope Francis Calls for a Stronger System of Global Governance, 2015 (on-line), at: http://papalvisit.americamedia. org/2015/09/25/pope-francis-calls-for-a-stronger-system-of-global-governance/, accessed 29th September 2016.

31 Brian J. HEHIR, Globalization and Global Governance, in: The Moral Dynamics of Economic Life: An Extension and Critique of Caritas in veritate, ed. Daniel K. FINN, New York, 2012, p. 58. 
Thomas D. Williams reflects on the ongoing debate as well as on the fundamental objections against the concept of global governance. ${ }^{32}$ He perceives the scepticism concerning the functioning of the UN and its defects, and does not overlook the argument that international institutions are difficult to control by citizens or the traditional argument of fear of the impossibility to escape from the reach of a government with a worldwide reach. At the same time he is aware that opposition to the idea of supra-national governance is generally strongest from the perspective of the USA as a superpower and can stem from the fact that precisely that country principally has nothing to gain by shifting governance to the supra-national level, while it can lose much. Williams first shows that the doctrine of world political authority is not new: it is fully consistent with the preceding tradition associated with the idea of the common good. The common good exists at all levels of human society including international space and the whole of humanity. Besides the individual particular goods of different human groups, which require levels of governance and authority, in the context of globalization it is increasingly possible to discern the universal common good (commune bonum universale) of the whole human family. Although in the past the universal common good may have appeared as an abstraction and an authority securing this good as a faraway prospect, in the situation of intensifying interactions within the whole of humanity its necessity is becoming manifest. Since the time of John XXIII the global character of the common good has become increasingly more apparent (which is why he was the first to speak of a world political authority), while Benedict XVI speaks of the 'explosion of worldwide interdependence, commonly known as globalization ${ }^{33}$ and therefore logically emphasizes global authority. Williams also believes that it was precisely the encyclical CV that brought many new clarifications and shifts concerning the conception of universal authority. In that he points out a fundamental shift in the perception of global authority towards decentralized, subsidiary and multilevel governance, especially with respect to the encyclical's $57^{\text {th }}$ section ('In order not to produce a dangerous universal power of a tyrannical nature, the governance of globalization must be marked by subsidiarity, articulated into several layers and involving different levels that can work together.'). Thereby this concept of world political authority approaches the concept of global governance, normally understood as multilevel governance without a central authority. According to Williams, Benedict shifts the concept 'beyond the less developed understanding of global governance as expounded by his predecessors John XXIII and Paul VI. ${ }^{34}$

\section{More critical views of world political authority}

Let us now focus on more critical views, which rather see the risks and problematic aspects in the concept of world political authority. While Thomas D. Williams (discussed above) believes that the new conception of world political authority in CV is close to the concept of GG conceived as multilevel governance without a central authority, John A. Coleman disagrees with this view. In his view Benedict XVI 'lacks imagination in dealing with dilemmas of global governance. ${ }^{35} \mathrm{Al}$ though he includes subsidiarity, multi-level character, transparency and morality in his concept, it still seems to him that he relies too much on the vertical dimension of authority and intergovernmental institutions:

32 Cf. Thomas D. WILliAMS, The World As It Could Be. Catholic Social Thought for a New Generation, USA: The Crossroad Publishing Company, 2011, pp. 112-128.

33 CV 33

34 Thomas D. WILLIAMS, The World As It Could Be, p. 118.

35 John A. COLEMAN, From Government to Governance, in: The Moral Dynamics of Economic Life, ed. Daniel K. FINN, p. 59. 
To become more effective and credible in globalization debates, Catholic social thought needs to pay more attention to multiple global governance forms and the ethical criteria needed to judge these institutions. Catholic social teaching talks little about regimes and global policy networks. But the lofty and often vague talk about a global common good demands more than attention to the United Nations and other international governmental organizations. In sum, official Catholic social thought seems overly fixated on governments and government-controlled institutions and not attentive enough to alternative forms of global governance. These alternative forms of governance are becoming more and more important in providing an ethics-based framework for global life, a fundamental recommendation of Caritas in veritate. ${ }^{36}$

In an older paper $^{37}$ John A. Coleman describes his views and preferences concerning global governance in detail. He prefers a greater emphasis on regimes and global political networks, including a broad spectrum of agents of global civic society. He finds most incentives for developing GG in the document Our Global Neighbourhood (1995) published by the Commission on Global Governance, which calls for substantially greater involvement of 'civic society' in decisions of global government institutions, even in the sense of instituting a new 'quasi-parliament' consisting of representatives of NGOs, which would be a counterbalance to the UN General Assembly consisting of representatives of national states.

A similar view is taken by Marián Sekerák: in his paper Towards a Worldwide (Deliberative) Democracy? Catholic Social Teaching and the Idea of Global Governance $(2016)^{38}$ he labels the concept of world political authority in Catholic social teaching as rather rigid, too tributary to an institutional approach and too dependent on the established structures of the UN. He advocates more a profound application of the principles of deliberative and participative democracy in the context of global governance - although Catholic social teaching has adapted the concept of democracy, it does not pay sufficient attention to it and does not put it in a deeper context with the concept of world political authority. That ought not to be based solely on an institutional approach oriented on states, international organizations and formal authorities, but especially on applying the powers and activities of 'global civic society', which would go by the path of global deliberations towards a networked, non-hierarchical and non-institutional exercise of global authority.

In the debate following the publication of the encyclical Caritas in veritate the idea of a global political authority was also criticized, for example, by George Weigel. He suggests ${ }^{39}$ that the revitalization of the concept of world political authority and other paternalistic sounding recipes may be due to inadequate influence of IUPAX, which prepared the document draft. According to Weigel, IUPAX, which presents itself as the Vatican custodian and interpreter of CST, represents its old-fashioned, outdone authoritarian vision. When John Paul II received a draft of the encyclical Centesimus annus from that council he allegedly found it unusable and preferred to write the whole encyclical himself anew - in the spirit of emphases on freedom, creativity, appraisal of the

36 Ibid., p. 60 .

37 Cf. John A. COLEMAN, Global Governance, the State and Multinational Corporations, in: Globalization and Catholic Social Thought, eds. John A. COLEMAN and William F. RYAN, New York, 2005, pp. 239-248.

38 ○ Marián SEKERÁK, Towards a Worldwide (Deliberative) Democracy? Catholic Social Teaching and the Idea of Global Governance. Italian Political Science Review / Rivista Italiana di Scienza Politica 3/2016, pp. 1-22 (on-line), at: http://journals.cambridge.org/action/ displayAbstract?fromPage $=$ online\&aid=10258868\&fileId=S0048840216000046, accessed 29th September 2016.

39 Cf. () George WEIGEL, Caritas in Veritate in Gold and Red, National Review, 2009 (on-line), at: http://www.nationalreview.com/ article/227839/caritas-veritate-gold-and-red-george-weigel, accessed 29th September 2016. 
market economy, democratic values, as well as criticism of paternalistic social states. According to Weigel, a similar situation allegedly took place also in the case of the encyclical CV, which was to be published in 2007 to commemorate the $40^{\text {th }}$ anniversary of the encyclical Populorum progressio (1967). Its publication was held up by two years - allegedly because Pope Benedict XVI was so dissatisfied with the drafts formulated by IUPAX that he repeatedly returned them for reformulation. In this context Weigel points out a certain double-layered, 'hybrid' character and incoherence of the encyclical's text, which on the one hand develops the realist tradition of thinking characteristic of John Paul II and Benedict XVI inclining to freedom, and on the other hand under the influence of IUPAX seeking to return to the paternalistic and partially utopian thinking characteristic of John XXIII. Weigel sees the influence of IUPAX among others in the revitalization of the concept of global political authority:

\begin{abstract}
And another Justice and Peace favourite - the creation of a 'world political authority' to ensure integral human development - is revisited, with no more insight into how such an authority would operate than is typically found in such curial fideism about the inherent superiority of transnational governance. (It is one of the enduring mysteries of the Catholic Church why the Roman Curia places such faith in this fantasy of a 'world authority', given the Holy See's experience in battling for life, religious freedom, and elementary decency at the United Nations.)
\end{abstract}

It is interesting that subsequently, in Pope Francis, Weigel observes no fundamental preference for a world political authority and does not comment on it. Francis himself does not prefer the concept and his texts rather suggest a certain wariness. Nonetheless, Daniel J. Mahoney, for example, in the paper Laudato Si' and the Catholic Social Tradition $(2015)^{40}$ finds that Francis has 'remarkable faith in the capacity of an elite of international technocrats to govern the world'. But Mahoney doubts that these elites are favourably inclined to the Christian vision of the human person and respect human freedom, the requirements of subsidiarity, decentralization and autonomy. On the other hand he suggests that Pope Francis may be criticizing the idea of a 'world state' while criticizing the 'technocratic paradigm' of governance and the economy.

A radical critic of global institutions and of a consolidating global order is Michel Schooyans, whose radical criticism of the global concepts of governance represents one of the extreme positions of criticising GG. Fundamental for his attitude is criticism of the existing forms of global governance, and not primarily of its debated and asserted future possible forms. Schooyans is Professor Emeritus at Université Catholique de Louvain and a long-term member of important Vatican academies including PASS, both active and emeritus. In his book The Hidden Face of the United Nations $(2001)^{41}$ he focuses on the activity of the UN, which he claims has radically departed from its original roots and tends to assert 'new human rights' and a global superstate. While he regards the Universal Declaration of Human Rights of the $U N$ as an excellent contribution to secure human dignity and rights, he sees the later development of the human rights agenda as highly problematic. He finds radically destructive elements in the functioning of the existing structures of global governance and global management of development, health and human rights - he is thinking of the rights that John Paul II usually identified with the so-called 'culture of death', i.e., rights revising the traditional view of dignity of life, marriage, sexuality, etc. He writes:

40 Cf. (C) Daniel J. MAHONEY, Laudato Si' and the Catholic Social Tradition, 2015 (on-line), at: http://www.nationalreview.com/article/425349/laudato-si-catholic-social-tradition-pope-francis, accessed 29th September 2016.

41 Michel SCHOOYANS, The Hidden Face of the United Nations, St. Louis: CCVA, 2001. 
This inverted, purely 'positive' or voluntarist conception of man's rights obviously destroys the principle of subsidiarity, prerequisite of all international society and keystone of all democratic thought. ${ }^{42}$

What he calls the 'new totalitarianism' and 'totalitarian juridical voluntarism' of the UN by all means weakens nations and their identity; it comes with a deformed 'anthropological revolution'. An anthropological conception of human rights based on natural law is being replaced by holistic, relativistic and positivistic approaches:

The world community and nations signatory to the 1945 Charter and 1948 Declaration are on the way toward switching to an opposite form of man's rights that no longer has anything to do with the founding bases of the UN. This form, which tends to be imposed cunningly, is a prelude to the impossibility of a democratic society. ${ }^{43}$

Through the individual UN agencies, especially the World Health Organization and the Population Fund, whose agenda is infiltrated by the influence of Malthusianism and hedonism, this agenda is asserted with the effort to reduce the size of the population, especially in developing countries. For them the UN as a whole is a 'worldwide directorate ${ }^{34}$ based on a historically unprecedented concentration of power, ${ }^{45}$ whereby the UN Security Council, which functions according to the principle of dominance over the UN General Assembly, is allegedly the foundation for a system of world government. ${ }^{46}$ Schooyans's newer book The Gospel: Confronting World Disorder $(1997)^{47}$ is similarly worded: the author identifies the EU as an effective branch of global governance, which according to him 'became a victim of an unprecedented project of ideological colonization'. ${ }^{48}$ He views European integration, especially after Maastricht, as problematic especially because the individual countries are giving up their sovereignty and democratic self-government which would facilitate their independence and resistance to the invasion of deformed human rights and ambitious ideologies authoritatively streaming in from supranational structures. So both books imply the view that the already existing structures of global governance and global management of development, health and human rights are fundamentally dangerous and key agents of spreading a deformed image of man and the value framework figuratively called the 'culture of death'.

\section{The dilemma between weak and strong global governance in the broader Catholic debate}

The variable interpretative potential of CST documents as well as the opinion and ideological background of the individual representatives of Catholic social thought leads, to some extent understandably, to quite different and often contrary opinions in many spheres of political and economic reality, including the idea of global governance and the constitution of a possible world po-

47 Cf. the Slovak translation Michel SCHOOYANS, Evanjelium. Ako čelit’ svetu v rozvrate?, SR: Inštitút Leva XIII., 2010.

48 Ibid, p. 111. 
litical authority. I will now attempt to partially structure and evaluate them. In the context of the debate within Catholic social thought the 'strongest' concept is the already mentioned Report to COMECE Bishops, which expects a gradual transformation of international institutions towards 'supranationalism', following the exemplar of the institutional and functionalist architecture of European integration. It rather surprisingly and unrealistically expects a broad global consensus regarding values and goals. The Eurocentric perspective of this document and its authors is augmented by the request that the Charter of Fundamental Rights of the EU becomes the global foundation of human rights, perceived here as a universal expression of human rights. Even though it is an interesting development of the concept, it is strongly and unrealistically biased by a narrow European perspective and utopian features, and is also hardly compatible with CST documents and the opinions of the Popes, who to a large extent associate global governance with the UN and the foundation of human rights with natural law, or with the Universal Declaration of Human Rights of the UN. The requirements for global governance are understood in a similarly strong manner, for example by Kevin Ahern, who believes that in the context of contemporary global challenges it is necessary to erect an effective and robust supranational authority. He even finds the IUPAX note mentioned above too correct, mild and abstract, and can imagine even more radical forms. But at the same time he quite incorrectly and a-historically claims that the Catholic Church has been a proponent of strong supranational governance since the Middle Ages.

The PASS platform mentioned above is an excellent contribution to the debate on global governance, in which a whole spectrum of opinions is sounded. Except for the first two scholars (Bjorkman and Crocker) all the others mentioned (Archer, Llach, Possenti, Kuan, Tietmeyer, Buttiglione and Matlary) are members of it. Their opinions are mostly rather sceptical and wary of a strong concept of global governance with a preference for a moderate reform of the existing platforms, the horizontal coordination of global governance and the rejection of the possibility that a legitimate global authority could realistically be instituted. Possenti is a certain exception, for he advocates his concept which is more associated with vertical authority and a weak role of the national states; he even speaks of a 'strong cosmopolitanism', which for reasons of historic urgency ought to be applied even at the cost of a certain resignation on consensus and for which the structures of the UN are merely a weak predecessor. The incentives of Kuan, Buttiglione and Matlary can be even regarded as more strongly critical of the possibilities of applying a stronger concept of global governance. Tietmeyer openly evaluates the papal concept of 'global political authority' as unrealistic, vague and impractical, whereby he prefers to develop and improve the existing institutions rather than create new ones. Although these more critical authors express the hope that global democratic mechanisms will be asserted in the future, at the same time they mention the risks - decadent moral trends in the already existing UN structures, the non-existence of a 'global civic society', risks of international activism applying a deformed conception of values, and limits of democratic legitimacy for international institutions. Kuan even warns against a hasty generalization of a specifically European path of integration and the efforts to apply it at global level, because of its unique specific historical and ideological context. Some authors such as Williams interpret the concept of world political authority within the framework of decentralized GG as 'governance without a government' and point out the more developed and less 'authoritarian' understanding of the concept in Benedict XVI, as compared to the older conceptions in John XXIII and Paul VI. On the other hand, authors such as Weigel, Coleman or Mahoney understand the concept of world political authority in CST as a certain relic of scholastic and authoritarian thinking, placing an overt emphasis on the vertical dimension of authority and intergovernmental institutions. Weigel even labels it as a relic 
of paternalism and utopianism, based on a difficult-to-understand faith in the possibility of a 'good' global government despite historical experience. Coleman and Sekerák are also concerned about a strong vertical authority and request a greater emphasis on plurality and the participation of a broader spectrum of subjects in the processes of global governance, especially of non-profit organizations. Mahoney expresses doubt concerning the real application of Christian values in the context of global governance structures and raises the rhetorical question of why Pope Francis perceives strong supranational institutions as a hope for a solution, rather than as part of the problem of the governing 'technocratic paradigm' of which he is so critical. The strongest critic of existing or further developing forms of global governance is Schooyans, according to whom the already existing structures of global governance and global management of development, health and human rights are in essence identical with those who spread the so-called culture of death. He has no illusions of the possible constitution or revitalization and possible principal change in these institutions and in essence requests a return to the basic ideals of the UN and the Universal Declaration of Human Rights of the UN, which he regards as a certain formulation of natural law.

\section{Conclusion}

It is evident that the debate concerning global governance and the concept of world political authority is highly colourful and multifaceted; it does not provide an unambiguous CST position on global order. As I have indicated, the interpretative potential of CST documents is fairly broad and enables argumentation with different emphases. Since the individual Popes and documents place different emphases, it is quite difficult to formulate the CST view of world political authority into a certain coherent whole, so that it could be, for example, compared to the opinions held in the debate concerning the GG concept in international relations theory. But taking a step back from the often demanding requirements that are difficult to realize which the encyclicals present as certain ideals, and recalling some papal evaluations of the real practice of international institutions, one can see that the specified notion is not too far removed from really existing international global institutions. The Popes quite conservatively regard the UN structures as the basic platform of global governance and world political authority. John Paul II underlined that he does not see a future in finding a new and correct, as yet undiscovered, form of international institutions or a new global power centre beyond the framework of the existing forms, but rather in that it is primarily necessary to incorporate a stronger assertion of moral values - human rights, transparency and democratization - into the present institutions. That is even how he retrospectively interprets the view of John XXIII, who according to him viewed the UN with hopes because he 'saw in it (...) a trustworthy instrument of maintaining and reinforcing peace in the world', protecting human rights and human dignity ${ }^{49}$ Similarly Benedict XVI's Address to the UN $(2005)^{50}$ shows that he sees no principal difference between the concept of 'optimal' world political authority and the UN project, though he does have reservations:

Through the United Nations, States have established universal objectives which, even if they do not coincide with the total common good of the human family, undoubtedly represent a fundamental part of that good.

49 Cf. Message of His Holiness Pope John Paul II for the Celebration of the World Day of Peace, January 1 $1^{\text {st }}, 2003$, art. 5.

50 (c) Address of His Holiness Benedict XVI to the General Assembly of the United Nations Organization, April 18 ${ }^{\text {th }}, 2008$ (on-line), at: http://w2.vatican.va/content/benedict-xvi/en/speeches/2008/april/documents/hf_ben-xvi_spe_20080418_un-visit.html, accessed $30^{\text {th }}$ November 2016. 
Benedict retrospectively interprets John Paul II's requirement as basically fulfilled and states that 'the United Nations embodies the aspiration for a "greater degree of international ordering" (John Paul II, Sollicitudo rei socialis, 43), inspired and governed by the principle of subsidiarity, and therefore capable of responding to the demands of the human family through binding international rules and through structures capable of harmonizing the day-to-day unfolding of the lives of peoples.'

Thereby he indicates that neither he nor John Paul II principally think of some qualitatively higher level of international ordering beyond the UN. Pope Benedict XVI speaks of the need to 'reform the UN organization and the international economic and financial architecture', but he sees the ideals sketched out in the UN Charter as the starting point. ${ }^{51}$

Similarly Pope Francis in his Greetings to the UN Personnel (2015) ${ }^{52}$ exalts the 'praiseworthy international juridical framework' of the UN, which has some imperfections but 'can be the pledge of a secure and happy future for future generations'. At the same time he lays an emphasis on legal instruments of limiting global power, the risk of disproportionate power in the hands of nationalistic or 'falsely universalist ideologies' and at the same time warns against 'the creation of an all-powerful élite'. Francis sees the key to reform in an emphasis on the equality of state agents - 'reform and adaptation to the times is always necessary in the pursuit of the ultimate goal of granting all countries, without exception, a share in, and a genuine and equitable influence on, decision-making processes. The need for greater equity is especially true in the case of those bodies with effective executive capability, such as the Security Council, the Financial Agencies and the groups or mechanisms specifically created to deal with economic crises'. Francis's evident preference for the traditional 'inter-governmental approach' to the detriment of transnationalism, despite the declared emphasis on the efficiency of international institutions, shines through especially in his less formal speeches: 'Nations must not lose their freedom. A nation has its culture and history, but when colonial empires dictate their conditions, they strive for a loss of national identity and establish sameness, ${ }^{53}$ or 'the future of humanity is not only in the hands of great leaders, great powers and élites. It is first of all in the hands of nations; in their ability to organize and also in their hands which humbly and convincingly water this process of change'. ${ }^{54}$

Drawing on the above evaluations of the last three Popes, who witnessed the functioning of the UN after the end of the Cold War in the context of ongoing globalization, it is possible to conclude that with respect to the debate going on in Catholic social teaching the Popes see the structures and authority of the UN as the primary basic platform of global governance and world political authority. If they call for these structures to be reformed, they mostly limit the call to the requirement of harmonizing the activities of the UN with the moral postulates of the natural law, basic human rights, or greater democratization. This position in fact converges with the more conservative and warier views of stronger concepts of global governance in the broader spectrum of Catholic social thinking and principally contradicts the 'progressivist' views of radically more extensive global institutions. In other words - if the UN fulfilled its declared goals and rigorously

51 Cf. CV 67.

52 (C) Greetings to the UN Personnel, New York, 2015 (on-line), at: http://w2.vatican.va/content/francesco/en/speeches/2015/september/ documents/papa-francesco_20150925_onu-saluto.html, accessed 30 ${ }^{\text {th }}$ November 2016.

53 (C) Tisková konference spapežem Františkempři návratu z Filipín, 2015 (on-line), at: http://www.radiovaticana.cz/clanek.php4?id=21363, accessed $29^{\text {th }}$ September 2016.

54 (C) Globální sociálně-ekonomický systém útočí na Ježí̌̌io plán. Promluva papeže na setkání se stoupenci alternativní ekonomiky, Bolívie, 2015 (on-line), at: http://www.radiovaticana.cz/clanek.php4?id=22110, accessed $29^{\text {th }}$ September 2016. 
emphasized respect to the human rights formulated by it, it would in the Popes' view embody the ideal of the world political authority they define. So the Popes' position, as far as the context of the debate in international relations theory is concerned, is mostly in terms of classical liberal institutionalism. In their universalistic hope for the possibility of creating high-quality efficient institutions, they in some aspects approach cosmopolitanism, but at the same time it does not identify with the uniform cosmopolitan vision of human beings and human communities. It coincides with transnationalism in the emphasis on democratic ethos and the requirement that non-state subjects take a participatory role. There is even a link between Catholic social teaching and critical theories - it views the existing structures as problematic, hegemonic and asymmetric, with a deformed ethos. But a more profound comparison of the positions of CST with theories in the sphere of the study of international relations would require an independent investigation. Another separate topic would be a certain comparison of the Catholic positions on the issue of world political authority and global order with other denominations; the thematic documents of the World Council of Churches ${ }^{55}$ suggest themselves, or those of Orthodox Christianity, ${ }^{56}$ or possible intersections and inspirations in non-Christian religions.

So the emphasis of the UN platform without doubt does not exclude the possibility of certain institutional and functional modifications with respect to the historical transformations of the security, political and economic conditions, while at the same time it does not mean a step aside to an altogether different form of international ordering (according to the IUPAX note, or the exemplar of EU transnationalism, or by preferring the IMF platform to the UN as proposed by the Report to COMECE Bishops, or according to Possenti's vision of 'strong cosmopolitanism'). Of course, the more progressive and radical views of global governance and of the power of global political authority are a certain radicalized reaction to the unsatisfactory state, crisis of legitimacy and long-term failure to fulfil the declared goals and ideals of the UN contained in the Charter or the Declaration. The analogy with other currently debated spheres of policy - for example, with the issue of a 'crisis of democracy' or a 'crisis of European integration' - show that the 'cure' for the problems that arise is not always radicalizing the ideal ('more democracy' or 'more Europe'), but rather a certain return to the (moral) essence, which holds all the more for global political organization.

On the other hand, some evaluations on the part of the 'more critical views' of the Catholic debate on global governance must also be regarded as radical and inadequate, especially in the sense that in the context of heightened debate they insert views into the interpretation of CST that are not directly implied by it (e.g. Weigel, Coleman, or Mahoney). A more complex evaluation of Pope Francis's speeches does not suggest that he harbours excessive trust 'in the capacity of international technocrats to govern the world', as Mahoney suggests - on the contrary, his sometimes 'anti-conspiracy'-sounding formulations mark a high level of distrust of strong and 'technocratic' global solutions.

To return now circuitously to the 'migration crisis', it can be regarded as a symptom of failure, of

55 Cf. e.g. ( ) WCC, Statement on UN Reform, 2006 (on-line), at: http://www.oikoumene.org/en/resources/documents/assembly/2006-porto-alegre/1-statements-documents-adopted/international-affairs/report-from-the-public-issues-committee/un-reform, accessed September 29th, 2016; or ( ) WCC, Economy of Life for All Now: An Ecumenical Action Plan for a New International Financial and Economic Architecture, 2014 (on-line), at: http://www.oikoumene.org/en/resources/documents/wcc-programmes/public-witness-addressing-power-affirming-peace/poverty-wealth-and-ecology/economy-of-life-for-all-now-an-ecumenical-action-plan-for-a-new-international-financial-and-economic-architecture, accessed $29^{\text {th }}$ September 2016.

56 Cf. COLLECTIVE OF AUTHORS, Základy sociální koncepce Ruské pravoslavné církve, Červený Kostelec: Pavel Mervart, 2009. 
unfulfilled and in the long term neglected basic UN objectives, especially those related to security and economy. In this case the platform of global governance and global solidarity is put aside by an effort at ad hoc solutions, whether consisting in transferring a disproportionate burden to Europe, or on the other hand in a rather situational defence of European interests, of doubtful moral relevance. A greater part of these problems cannot be solved on a long-term basis on the regional level, but precisely on the 'cosmopolis' level - although not in a way corresponding to the deformed 'technocratic paradigm', but by paths seeking the good of human beings as persons and the good of the whole of humanity as a community bound by moral unity and living in a common home.

\section{The Issue of 'World Political Authority' in the Broader Context of Catholic Social Thought}

\section{Abstract}

The paper entitled 'The Problem of "World Political Authority" in the Broader Context of Catholic Social Thought' discusses the concept of 'world political authority' formulated in the social teaching of the Church, with reference to the 'migration crisis' and the 'cosmopolitan principle'. It presents and reflects upon the broad debate in the context of Catholic social thought regarding the character of global political organization and the concept of global governance, especially in the last twenty years. It concludes that the social teaching of the Church identifies 'world political authority' especially with the United Nations, rather than with a radically progressive and extensive development of global political institutions.

Keywords: Migration Crisis, Social teaching of the Church, World Political Authority, Catholic Social Thought, UN, Global Governance

\section{Author contact}

Dr. Roman Míčka

University of South Bohemia, České Budějovice

Faculty of Theology, Department of Ethics, Psychology and Charity Work

Kněžská 8, 37001 České Budějovice

mickar@tf.jcu.cz 